ISSN: 0514-7336 — ISSN electrónico: 2386-3943

DOI: https://doi.org/10.14201/zephyrus202187125144

\title{
EARLY IRON AGE 'BLACK' GLASS IN SOUTHWESTERN IBERIA: TYPOLOGY, DISTRIBUTION, AND CONTEXT
}

\section{Vidrio 'negro' de la Primera Edad del Hierro en el Suroeste de la Península Ibérica: tipología, distribución y contexto}

\author{
Francisco B. Gomes
}

Centre for Archaeology of the University of Lisbon-UNIARQ. School of Arts and Humanities of the University of Lisbon. Alameda da Universidade.1600-214 Lisboa, Portugal. E-mail: franciscojbgomes@gmail.com. ORCID ID: https://orcid.org/0000-0003-0664-6374

Recepción: 30/01/2021; Revisión: 19/02/2021; Aceptación: 27/03/2021

AвSTRACT: In the past few years, deeply colored black-appearing glass has garnered a growing interest in the context of research on Iron Age glass technology and trade. The numerous 'black' glass beads found in Early Iron Age contexts of Southern Portugal have not however been considered in this discussion, and they remain largely unsystematized. In this contribution, a typological survey of these objects is presented which highlights their unusual concentration in a well-delimited area of Southern Portugal and their relatively circumscribed chronological setting. This is particularly striking when compared with other groups of beads, namely blue beads of various types, which are much more widespread and long-lasting. The global position of these beads is also considered, with typological comparisons and the few available compositional data suggesting that they may be the product of Punic, and perhaps specifically Carthaginian trade with the Western Iberian Peninsula. Finally, the possible specific historic context in which these beads arrived in Southern Portugal is considered.

Key words: Ancient Vitreous Materials; Pre-Roman Glass Beads; Southern Portugal; 'Orientalizing' Period; Punic Trade.

Resumen: En los últimos ańos, el vidrio de apariencia negra ha merecido un interés creciente en el ámbito de la investigación sobre la tecnología y el comercio del vidrio en la Edad del Hierro. Sin embargo, las abundantes cuentas de vidrio 'negras' halladas en contextos del Sur de Portugal no han sido consideradas en esta discusión, y aún están en gran medida por sistematizar. En esta contribución se presenta una visión general de su tipología que permite señalar su peculiar concentración en un área bien delimitada del sur portugués y su marco cronológico relativamente limitado. Este hecho resulta particularmente llamativo comparado con la amplia distribución y larga duración de los abalorios de otros tipos, en particular de las cuentas azules de varios tipos. Se considera también el contexto global de estos abalorios, que a tenor de sus paralelos tipológicos y de los escasos datos composicionales disponibles podrían corresponder a un producto del comercio púnico, y más específicamente cartaginés, con el extremo occidental de la Península Ibérica. Finalmente, se considera también el posible contexto histórico en el que estas cuentas llegaron al territorio meridional portugués.

Palabras clave: materiales vítreos antiguos; cuentas de vidrio prerromanas; Sur de Portugal; Período Orientalizante; comercio púnico.

Ediciones Universidad de Salamanca / @®@ 


\section{Pre-Roman 'black' glass: a brief introduction ${ }^{1}$}

The early first millennium $\mathrm{BC}$ was a pivotal period in the history of ancient glass in which the previous technological traditions, characterized by the use of plant ash as a flux for glass production (Henderson, 2013: 127-202) -High Magnesia Glasses (HMG, see Sayre and Smith, 1961)- were progressively substituted in most areas by a new 'recipe' based on the use of evaporitic minerals such as natron (Schlick-Nolte and Werthmann, 2003; Shortland et al., 2006: 522; Gratuze, 2009) -Low Magnesia Glasses (LMG, see Sayre and Smith, 1961)-.

Unfortunately, our current understanding of this technological transition is somewhat hindered by several factors. On the one hand, in the core areas where it seems to have taken place, namely Egypt and the Near East, both traditional archaeological research and more recent analytical approaches have clearly favored the earlier periods of glass history (Henderson, 2013: 160-167), while the early first millennium вс has received comparatively little attention (Schmidt, 2019: 136-151).

On the other hand, there may be specific conservation issues underpinning our skewed understanding of the glass of this period. In fact, there are reasons to believe that in an early phase of the production of LMG the artisans responsible for this innovation failed to realize that, unlike plant ash, evaporitic minerals do not contain sufficient levels of lime to ensure the production of a chemically stable glass, and that the addition of lime-bearing raw materials was required.

This may have resulted in the production of glass that was particularly susceptible to weathering and corrosion, and which may not have easily survived in the archaeological record (Shortland, 2012: 171172; Conte et al., 2018: 515), except in extraordinary circumstances such as those documented in

1 The research presented in this paper was developed in the framework of the CEec Project $A$ Consuming Sea: Mediterranean imports, identity and social representation in the Southern Portuguese Late Bronze and Early Iron Ages (CEECIND/01109/2018), financed by the Portuguese Foundation for Science and Technology (FCT). the by now well-known $10^{\text {th }}$ century BC tomb of Nesikhons, in Egypt (Schlick-Nolte and Werthmann, 2003, 2010), the glass assemblage of which offers a key to understand the lack of glass in contexts of the period in question.

Fortunately, in recent years the development of new research, especially from an archaeometric point of view, has begun to shed light on this process of technological transition and to highlight its internal complexity, identifying not only overlaps in time and space between HMG and LMG production traditions (Reade et al., 2009; Purowski et al., 2012; Stapleton, 2015; Conte et al., 2018; Purowski et al., 2020), but also the existence of a period of experimentation during the early history of the latter in which multiple 'recipes' and productions seem to have been used, resulting in some cases in quite characteristic productions (Gratuze, 2009).

Among these, one that has recently come to the fore in archaeometric research comprises objects -essentially beads- made of black-appearing glass. The appearance of these glass objects is generally due to the presence of high quantities of iron in their composition (see references below), which gives them a very dark green coloration which, in reflected light, reads as black or nearly black. While these Pre-Roman 'black' glasses have not received as much attention as their later, Roman counterparts, which have recently been the object of a very thorough in-depth study by P. Cosyns (2011; see also Cagno et al., 2014), they have received growing attention in recent research.

This upsurge in interest can be traced back to pioneering studies on Iron Age glasses from Pella, Jordan (Reade et al., 2009), and especially from France (Gratuze, 2009), while more recent, in-depth comparative studies of 'black' glass beads from Italy and Slovakia (Conte et al., 2016, 2018) have contributed to put this research subject at the forefront of research. Other relevant data on the dynamics of production and distribution of Pre-Roman 'black' glass include recent studies of examples from Carthage, Tunisia (Eremin et al., 2012), Poland (Purowski et al., 2012; Purowski et al., 2020) and Sardis, Turkey (Van Ham-Meert et al., 2019). 
Unlike other areas of Western Europe covered in the previously mentioned studies, the Iberian Peninsula has not been featured in discussions regarding Pre-Roman black glass. A number of reasons can be suggested for this fact, including a certain lag with regard to research on Iron Age glass in general, and Iron Age glass archaeometry in particular.

In fact, since the untimely demise of E. Ruano Ruiz, who in the 1990s spearheaded a pioneering effort to systematize Pre-Roman glass beads in Spain both from an archaeological (Ruano, 1996, 2000) and an analytical perspective ( $c f$. Palomar et al., 2009), there has been a lull in research on the subject with only a few -albeit very meritorious- exceptions (e.g., García-Heras et al., 2005; Martínez Plano and Vilaplana, 2014; Conde et al., 2016; Costa et al., 2019; Sánchez et al., 2019).

However, another objective reason for the lack of research into 'black' glass in Iron Age Iberia is probably its uneven distribution throughout the Peninsula. In fact, this particular chromatic range seems to be all but absent in most of the Iron Age glass bead assemblages published with any degree of detail ( $c f$. Ruano, 2000), except for those from one particular area, specifically Southern Portugal (Figs. 1-2).

Considering that research on Pre-Roman glass in this area is even less developed than in the rest of the Iberian Peninsula, it is not surprising that the significant concentration of 'black' glass beads in Southern Portuguese sites has been overlooked in recent research on the subject. However, these objects did receive some marginal attention in Portuguese scholarship, especially in the works of C. de Mello Beirão.

In the course of the pioneering works lead by this researcher a very significant number of glass beads was in fact retrieved in Early Iron Age sites and particularly in funerary settings, and 'black' beads are fairly common in these assemblages (Dias et al., 1971: 218-219; Beirão, 1972: fig. 5; 1986: 71, 89; 1990: 111-113). These examples deserved particular consideration, since the aforementioned author considered 'black' eye beads, which he dated generally to the $6^{\text {th }}$ century $\mathrm{BC}$, to be the earliest type

Ediciones Universidad de Salamanca / ®ఠ of glass adornments documented in the region, predating other common types, such as monochrome dark blue beads and turquoise eye beads (Beirão, 1986: 89).

While the idea of a chronological precedence of 'black' beads over blue ones did not stand the test of time (Fabiano, 2001: 205), the date proposed by C. de Mello Beirão for the former remains to a large extent valid, as will be discussed below. This fact sets 'black' eye beads aside from their blue counterparts, which seem to have been produced, distributed and/or used for a significantly longer period of time.

This being said, and despite the relative attention garnered by the presence of these unusual 'black' glass beads, no thorough study of their typology and distribution in Southern Portugal has so far been undertaken (see however Dias et al., 1971: 218-219). Such a preliminary study seems critically important if we are to understand the general context of these glass elements, and will be a necessary basis for future studies, namely archaeometric ones, aiming to shed light on the historical and technological context of the Portuguese material. For this reason, a survey of the available evidence will be presented next, before turning to a consideration of the global context of the Southern Portuguese 'black' glass beads.

\section{Early Iron Age 'black' glass in Southwestern Iberia: typology, chronology, and distribution}

\subsection{Typological survey of Early Iron Age 'black' glass beads in Southern Portugal}

As mentioned above, 'black' glass beads are a relatively common occurrence in the Early Iron Age of Southern Portugal, particularly in funerary contexts. While never quantitatively predominant in the more well characterized assemblages (see below), 'black' beads are often among the most numerous groups documented in each site, which suggests both that local communities had a particular 
taste for these elements and that their acquisition was relatively accessible, at least for a time.

However, and despite being documented in at least 26 individual sites -and possibly as many as 28
(Fig. 1)-, some of which have yielded comparatively large assemblages, 'black' glass beads show relatively little typological diversity. The examples so far documented correspond overwhelmingly to beads

\begin{tabular}{|c|c|c|c|c|c|c|c|c|c|c|c|}
\hline & & 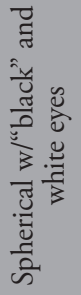 & 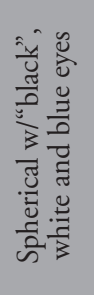 & 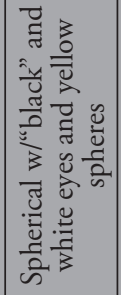 & 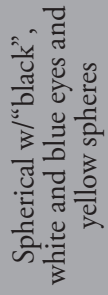 & 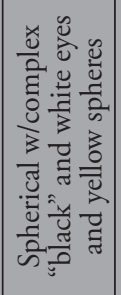 & 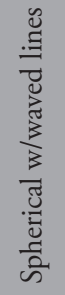 & 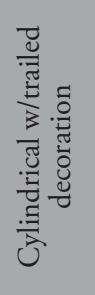 & 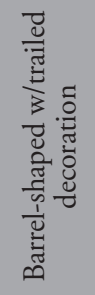 & 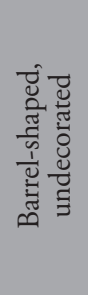 & 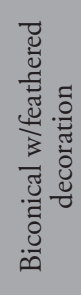 \\
\hline 1 & Fonte Velha de Bensafrim & $\bullet$ & & & & $\bullet$ & & $\bullet$ & & & • \\
\hline 2 & Corte de Père Jacques & $\bullet$ & $\cdot$ & & & & & & & & \\
\hline 3 & Gregórios & $\bullet$ & & & $\bullet$ & & & & & & \\
\hline 4 & Cômoros da Portela & $\bullet$ & & & & & & & & & \\
\hline 5 & Ameixial & $\bullet$ & & & & & & & $\bullet$ & & \\
\hline 6 & Alagoas & $\bullet$ & & & & & & & & & \\
\hline 7 & Faro & & & & & & & $?$ & & & \\
\hline 8 & Herdade do Gaio & $\bullet$ & & & & & & $\cdot$ & & & \\
\hline 9 & Almograve & $\bullet$ & & & & & & & $\bullet$ & & \\
\hline 10 & Pardieiro & $\bullet$ & & & & & & & & & \\
\hline 11 & Fonte Santa & $\bullet$ & & $\bullet$ & & & $\bullet$ & & & & \\
\hline 12 & Mealha Nova & $\bullet$ & & & & & $\cdot$ & & & & \\
\hline 13 & Pego & $\bullet$ & & & & & $\bullet$ & $\bullet$ & $\bullet$ & & \\
\hline 14 & Fernão Vaz & $\bullet$ & & & & & & & & & \\
\hline 15 & Chada & $\bullet$ & & & & & & & & & \\
\hline 16 & Cerro do Ouro & $\bullet$ & & & & & & $\bullet$ & & & \\
\hline 17 & Favela Nova & $\bullet$ & & & & & & & & $\bullet$ & \\
\hline 18 & Nora Velha & $\cdot$ & & & & & & & & & \\
\hline 19 & Corte Margarida & $?$ & & & & & & $\bullet$ & $\bullet$ & & \\
\hline 20 & Vinha das Caliças 4 & $\bullet$ & & & & & $\bullet$ & & & & \\
\hline 21 & Monte do Bolor 1-2 & $\cdot$ & & & & & & & & & \\
\hline 22 & Palhais & $?$ & & & & & & & & & \\
\hline 23 & Quinta do Estácio 6 & $\bullet$ & & & & & & $\bullet$ & & & \\
\hline 24 & Quinta do Castelo & $\cdot$ & & & & & $\bullet$ & & & & \\
\hline 25 & Poço Novo 1 & $\bullet$ & & & & & & & & & \\
\hline 26 & Fareleira 2 & $\cdot$ & & & & & & & & & \\
\hline 27 & Cabeça de Vaiamonte & $\cdot$ & $\bullet$ & & & & & & & & \\
\hline 28 & Almaraz & $?$ & & & & & & & & & \\
\hline 29 & *El Jardal & $\cdot$ & & & & & & & & & \\
\hline
\end{tabular}

FIG. 1. Early Iron Age sites with 'black' glass in Southern Portugal and types present in each site. 
with tendentially spherical morphologies -spherical to toroid and, less frequently, annular in shape-, to which a much more limited number of cylindrical, fusiform and biconical examples can be added. Almost all the documented examples are decorated with different patterns, generally in white, thus maximizing visual contrast with the dark background, and only very rarely in dark blue and/or yellow.

The most common group among the material so far documented comprises spherical to sub-spherical beads and some rare annular examples decorated with eye motifs (Figs. 3-4). These are most commonly formed by alternating layers of white and 'black' glass, and examples with just one layer in each color, or mono-stratified, and with several layers in each color, or pluri-stratified, frequently co-exist.

As for the disposition of the decorative eye motifs along the beads, different schemes can also be detected, including pieces in which they are disposed linearly along the surface of the piece, following G. Eisen's pattern A (Eisen, 1916: 13; see also Ruano, 1995a: fig. 4 ), and examples in which these motifs are disposed alternatingly along two planes, in a design more akin to scheme c) of M. Spaer (1985).

Not a lot of morphometric analyses for this class of beads are available, but an observation of the material clearly indicates that this group can further be divided into different size modules. This has been clearly demonstrated for the assemblage of Fonte Velha de Bensafrim, Lagos, in which three discreet modules were clearly identified, with diameters ranging from 0.8 to $1.3 \mathrm{~cm}, 1.45$ to $1.65 \mathrm{~cm}$ and 1.7 to $1.8 \mathrm{~cm}$ (Gomes, 2020: 99) (Fig. 3), while in the material from Fonte Santa at least two such modules can also be observed, with diameters ranging from 0.75 to 1.2 $\mathrm{cm}$ and 1.6 to $1.9 \mathrm{~cm}$ (Fig. 4). Other assemblages, such as those from Gregórios, Silves (Barros et al., 2005: Fig. 4), Fernão Vaz, Ourique (Beirão, 1972:

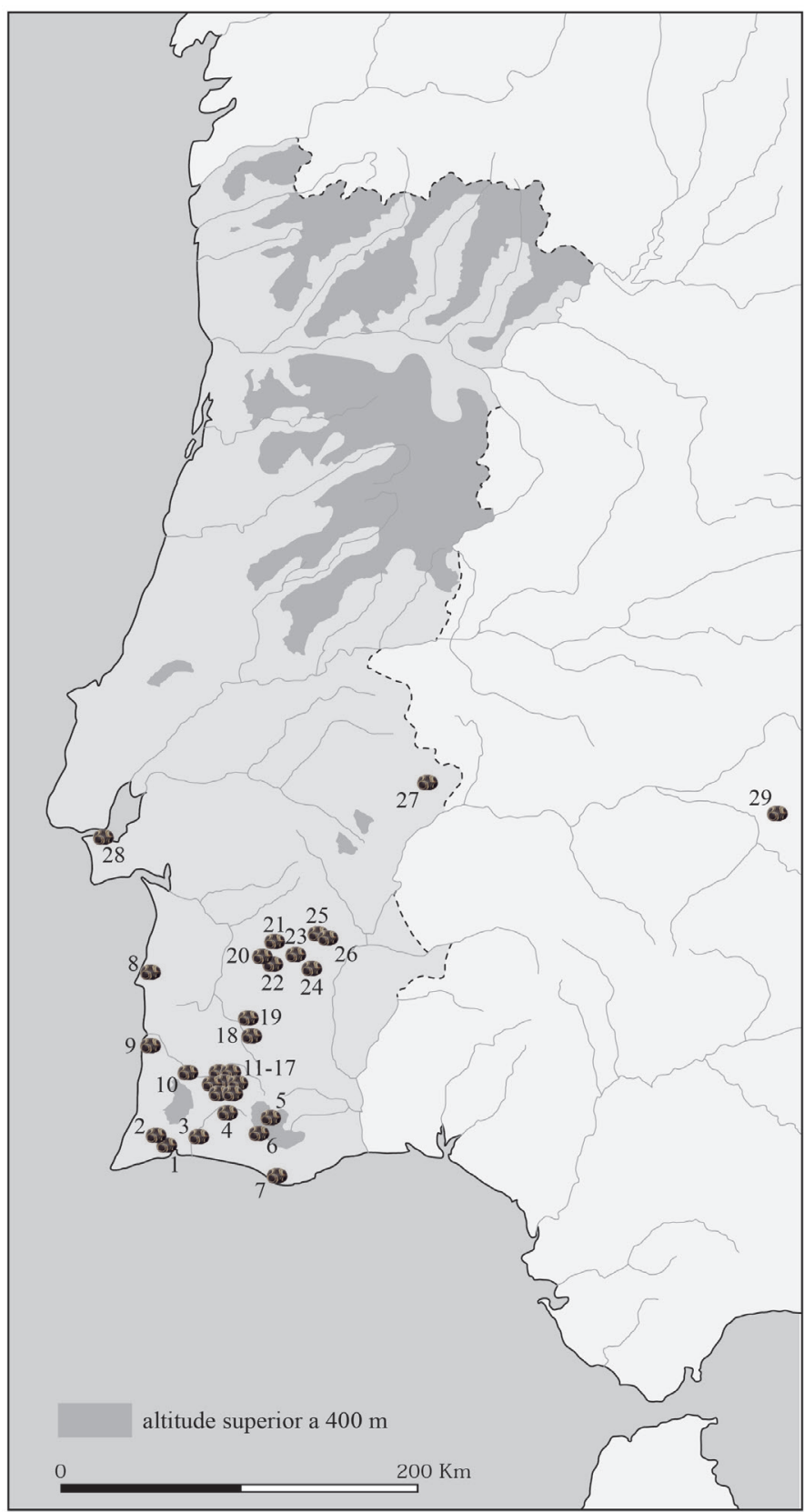

FIG. 2. Distribution of Early Iron Age 'black' glass in Southern Portugal; the numeration of the sites correlates to that in the table presented in Fig. 1 (cartographic base: V. S. Gonçalves).

fig. 5), and Monte do Bolor 1-2, Beja (Soares et al., 2017: fig. 18), seem to show a similar pattern.

As mentioned earlier, this group of 'black' beads are by far the most common in Southern Portugal. They are particularly well attested in funerary 

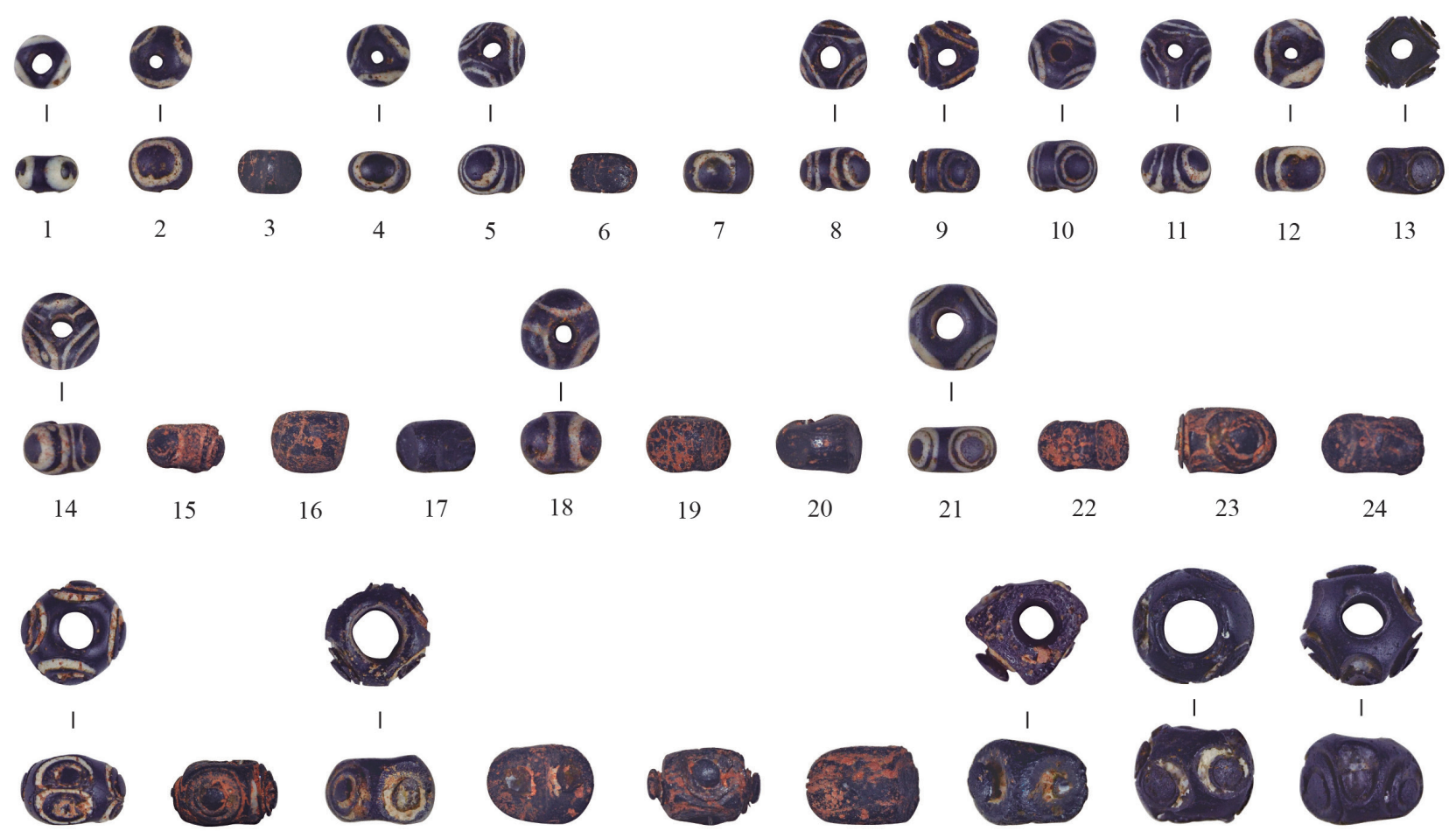

27

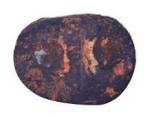

28

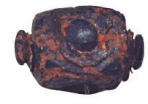

29
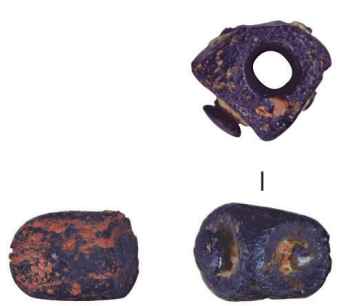

30
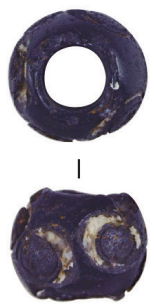

32

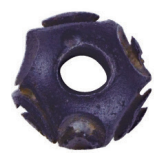

I

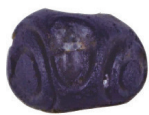

33

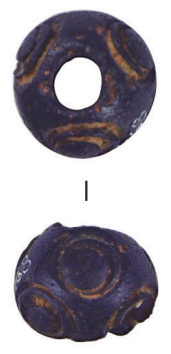

34
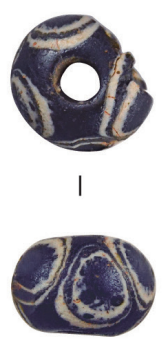

35
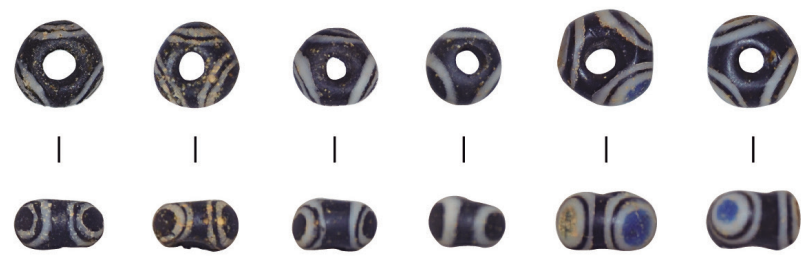

36
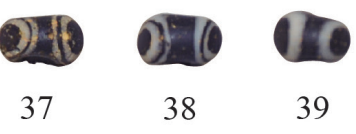

39

41

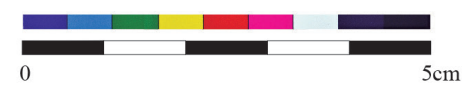

FIG. 3. 'Black'spherical eye beads from Fonte Velha de Bensafrim (nn. 1-35) (after Gomes, 2020) and Corte de Père Jacques (nn. 36-41) (after Gomes, in print). 
$\circ \circ 00000$ -10

$\begin{array}{llllllllll}1 & 2 & 3 & 4 & 5 & 6 & 7 & 8 & 9\end{array}$

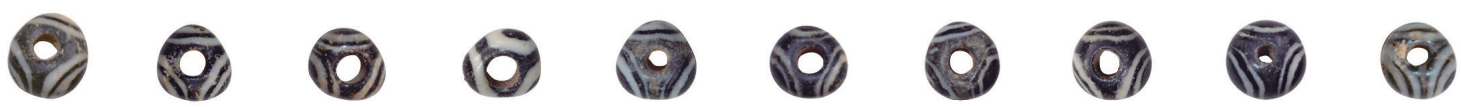

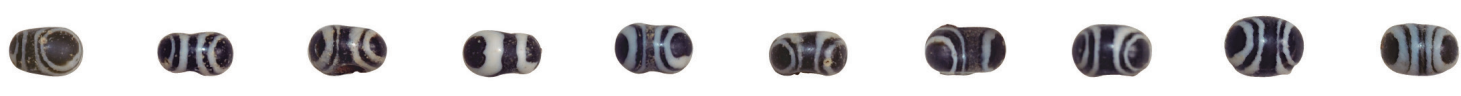

11

12

$\begin{array}{lll}13 & 14 & 15\end{array}$

16

$17 \quad 18$

1920

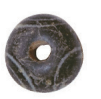

(2)

(8)

(9) 2
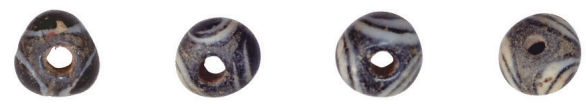

(2)
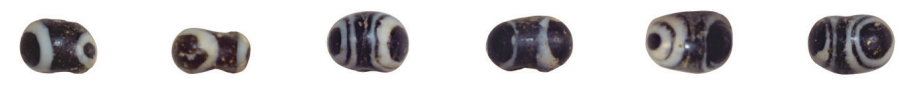

28

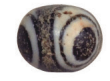

$21 \quad 22$

23

24

25

27

29
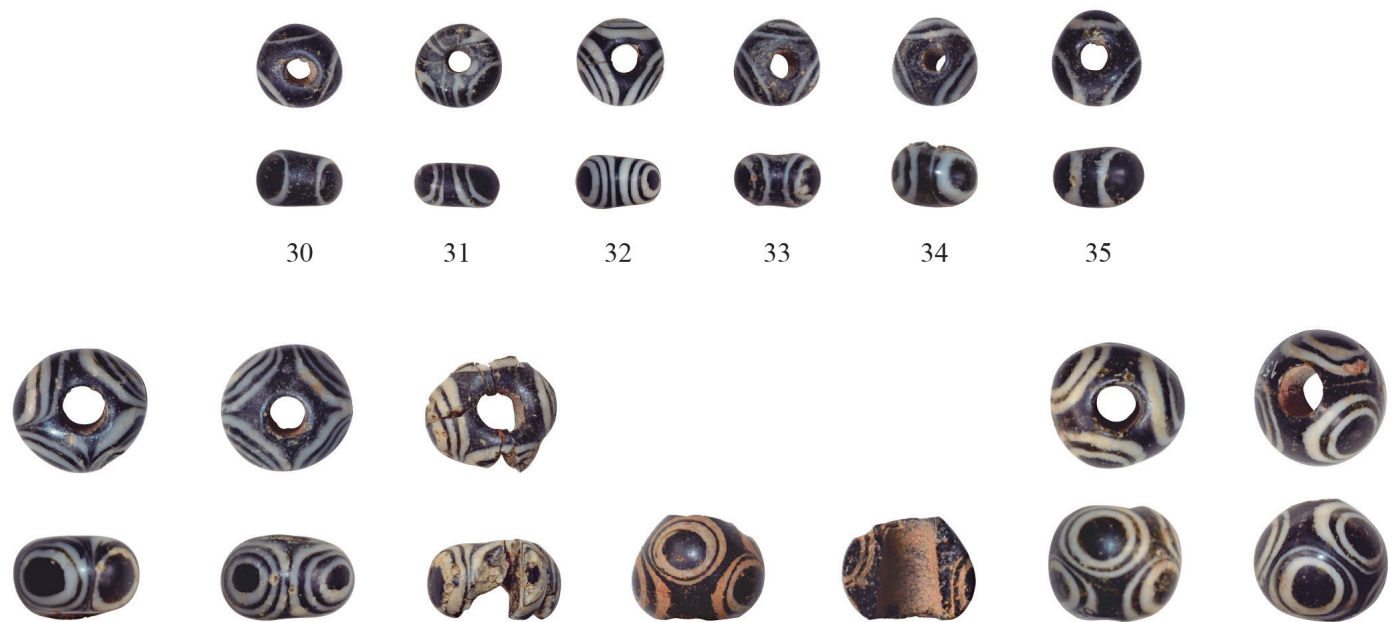

37

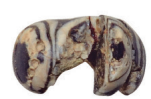

38

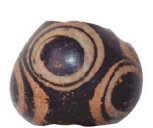

39
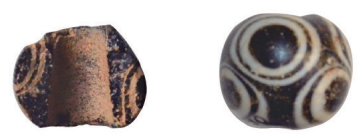

40

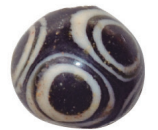

41
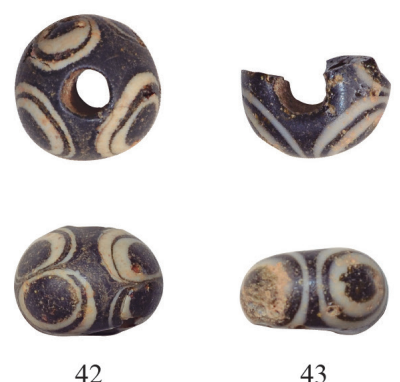

43

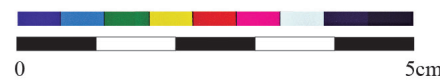

FIG. 4. 'Black'spherical beads from Fonte Santa (Ourique). 
contexts, both in the Algarve and in the Alentejo regions. In the former, significant assemblages have been found in the necropolis of Fonte Velha de Bensafrim, which yielded 39 examples $-13.2 \%$ of the total assemblage ${ }^{2}$ (Gomes, 2020: 90, 99101) (Fig. 3, nn. 1-35)-, and in the cist tomb of Gregórios, in which a likely necklace comprising 16 such beads was found associated to a female burial (Barros et al., 2005: fig. 4).

A smaller number of pieces has also been documented in the necropolis of Corte de Père Jacques, Aljezur -four examples, c. $6.8 \%{ }^{3}$ (Fig. 3, nn. 3639)-, Cômoros da Portela, Silves (Veiga, 2005 [1891]: 259; est. XxviII, n. 8), Alagoas, Loulé (Botto, 1899: 28; Vasconcelos, 1919-1920: 100), and Ameixial, Loulé (vv. AA., 2017: 252).

Further North, in the Alentejo region, a significant number of funerary sites have also yielded beads of the type in question. Significant concentrations can also be found in the poorly known necropolis of Almograve, Odemira, from which hail at least 15 'black' eye beads (Veiga, 2005 [1891]: est. Xxxi; Vilhena, 2014: fig. 5), and in the cist tomb(s) of Gaio, Sines, which contained 16 examples $-c .7 \%$ of the total glass beads (Costa, 1967, 1972).

In this coastal area of Alentejo, the case of the necropolis of Pardieiro, Odemira, should also be highlighted, as a large number of pieces of the type in question seems to have been retrieved. The exact amount is unknown, but the available publication mentions two such beads from Tomb 1, 85 from Tomb 4 and an unspecified number from Tomb 3, which formed a 70-bead necklace together with amber beads (Beirão, 1990: 111). Significantly, Pardieiro seems to be the only modernly excavated assemblage in which 'black' beads form the vast majority of the glass assemblage.

Further inland, in the necropolis of the Ourique region, several more assemblages of 'black' eye

2 Absolute and relative quantifications are only given when available, either from published literature or through the direct study of the material, and when the dataset is considered representative.

3 Gomes, F. B. (in print): "El vidrio prerromano en el Algarve (Portugal): el conjunto de la tumba de Corte de Père Jacques (Aljezur) en su contexto regional", Onoba, 9. beads have been documented. The assemblage of Fonte Santa, Ourique ( $c f$. Beirão, 1986: 71-74), formed by 44 individual examples $-33.1 \%$ of the total glass beads found in the site (Fig. 4)-, is one of the most relevant. To this, however, can be added the examples from the necropolis of Mealha Nova, Ourique, with 31 examples $-c$. $29.8 \%$ of the total glass assemblage-, Herdade do Pêgo, Ourique, with four examples -c. 40 \% (Dias et al., 1971: 218)-, and Fernão Vaz, Ourique, with 27 examples (Beirão, 1972: fig. 5), as well as those from Chada, Ourique -two examples (Beirão, 1986: fig. 29)-, Favela Nova, Ourique -one example (Dias and Coelho, 1983: 201-202)-, and Nora Velha, Aljustrel -one example (Soares and Martins, 2013: fig. 5).

Further examples are mentioned from the poorly known necropolis of Cerro do Ouro, Ourique -13 pieces (Beirão and Gomes, 1984: 442)-, while the presence of 'black' eye beads in the tombs of Corte Margarida, suggested by the figures accompanying the published reports (Deus and Correia, 2005), remains somewhat unclear.

In recent years, the identification and excavation of a significant number of Early Iron Age necropolis in the Beja region has revealed a particular concentration of 'black' eye beads in this area. These are well represented, for instance, in the large glass assemblage of Vinha das Caliças 4, Beja, with 55 examples - c. $6.9 \%$ of the total (Gomes, 2015: fig. 1; cf. also Arruda et al., 2017) -, but also in the necropolis of Monte do Bolor 1-2, Beja, in which the material from Tomb 4914-65 published examples- stands out for its volume and good preservation (Soares et al., 2017: fig. 18).

Another major concentration of 'black' eye beads seems to have been retrieved in the necropolis of Quinta do Estácio 6, particularly in Tomb 3 (Pereiro et al., 2017: figs. 9-10), while other, more isolated examples hail from the necropolis of Poço Novo 1 and Fareleira 2 (Figueiredo and Mataloto, 2017: figs. 8 and 10) and from Tomb 38 of Quinta do Castelo, which contained four such beads (Calvo and Simão, 2017: 404-405). The presence of beads of the type in question in the necropolis of Palhais is likely but remains as of yet unclear (Santos et al., 2017: 257). 


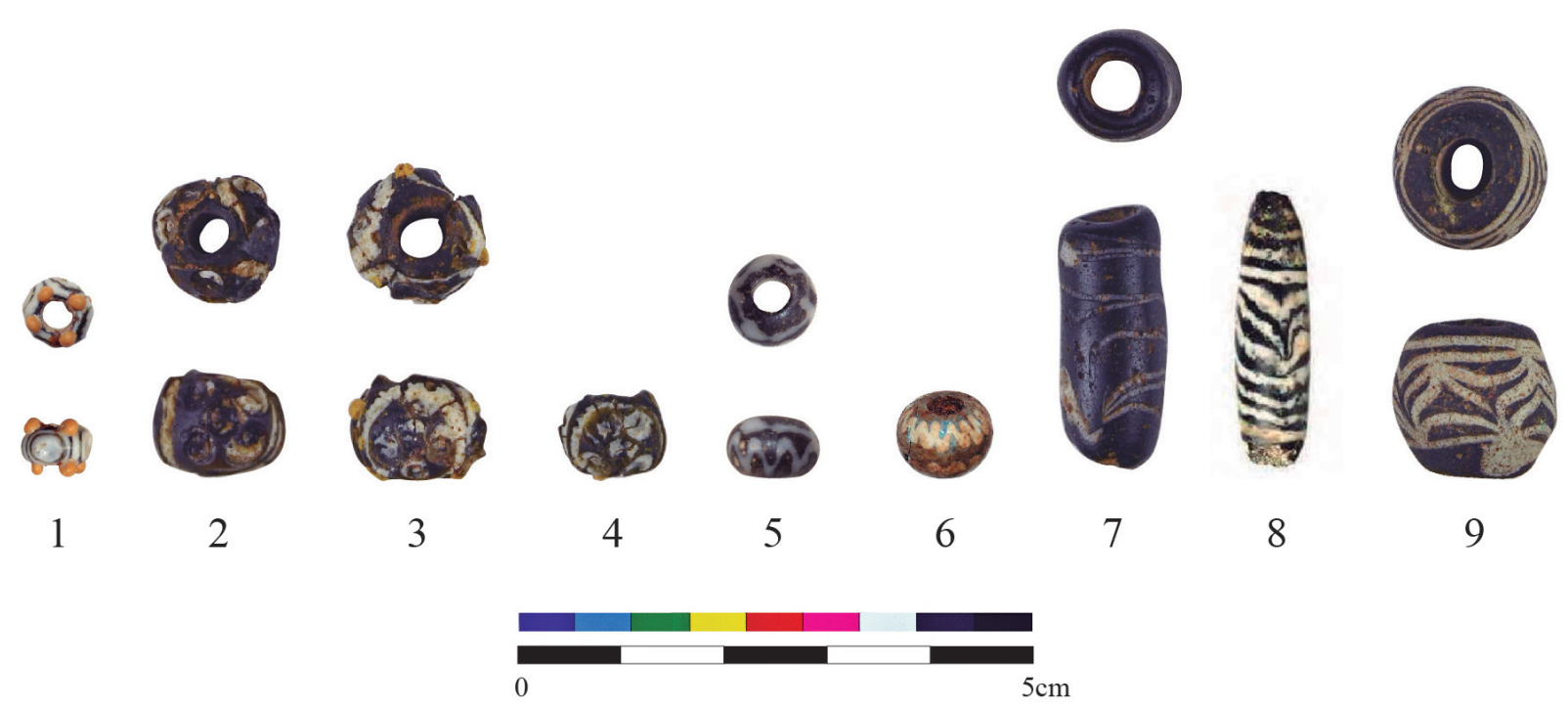

FIG. 5. Examples of the rarer groups of Early Iron Age 'black' glass beads found in Southern Portugal. Simple eye beads with applied yellow granules: 1) Fonte Santa, complex eye beads with applied yellow granules: 2-4) Fonte Velha de Bensafrim (after Gomes, 2020), spherical beads with waved line decorations; 5) Fonte Santa; 6) Vinha das Caliças 4 (after Arruda et al., 2017), cylindrical beads with trailed decoration; 7) Fonte Velha de Bensafrim (after Gomes, 2020), fusiform beads with trailed decoration; 8) Ameixial (after VV. AA., 2017), biconical beads with feathered decoration; 9) Fonte Velha de Bensafrim (after Gomes, 2020).

Only one further example is known from a funerary context outside Southern Portugal, namely a single piece retrieved in the necropolis of El Jardal, Badajoz, corresponding to $c$. $0.9 \%$ of that site's glass assemblage (Jiménez Ávila, 2001: 116).

'Black' eye beads are far less common in non-funerary settings, as only the very residual examples of Cabeça de Vaiamonte, Monforte - two examples, amounting to $0.2 \%$ of the total glass assemblage (Fabiâo, 2001: 204) - and a possible example from Quinta do Almaraz, Almada ${ }^{4}$, are known.

Closely related to the previous group, but far less common, are the spherical to semi-spherical beads with decorative eye motifs which combine white, 'black' and dark blue layers, the latter color being used for the central dot or 'pupil' of the decoration. This rare decorative combination has only been documented in two beads $-c .3 .4 \%$ of

4 Filardi, V. H.: Caracterização química de contas de vidro arqueológicas do século VII a. C. provenientes da Quinta do Almaraz, Cacilhas: fig. 1.6.1. MA Thesis presented to the New Univ. of Lisbon in 2011, available online at https:// run.unl.pt/handle/10362/8193; consulted on 22/01/2021. the total glass assemblage- from the necropolis of Corte de Père Jacques ${ }^{5}$ (Fig. 3, nn. 40-41) and in a single example from Cabeça de Vaiamonte $-0.1 \%$ (Fabião, 2001: 204).

Another minor group of beads closely related to the ones mentioned above comprise sub-spherical beads with decorative eye motifs which have further been decorated by the application of small yellow granules along their extremities. This more complex decorative pattern is again very rare, but different specific sub-groupings can still be differentiated.

These include typical sub-spherical 'black' beads with 'black' and white eye motifs, represented by a single example from Fonte Santa $-0.75 \%$ of the total glass assemblage (Fig. 5, n. 1)-, similar beads with 'black', white, and blue eye motifs, again documented by a single example from the Gregórios tomb (Barros et al., 2005: 49), and the more unusual beads with complex 'black' and white eye motifs -five dots inside a larger eye-, of which three examples are known from Fonte Velha de Bensafrim

5 Gomes, op. cit. n. 3. 
$-1 \%$ of the total glass assemblage (Gomes, 2020: 101-102) (Fig. 5, nn. 2-4).

A rarer but very interesting decorative group includes spherical to sub-spherical 'black' beads decorated with trails of white glass forming waved or zig-zag lines along the middle portion of the body. First documented in the necropolis of Mealha Nova and Herdade do Pêgo -one and two examples, or c. $1 \%$ and $20 \%$, respectively (Dias et al., 1971: 218)-, this particular type of bead is also present in Fonte Santa, where a single example $-0.75 \%$ - with a waved line topped by a more horizontal, albeit irregular line has been exhumed (Fig. 5, n. 5).

More recently, further examples have been detected among the glass assemblages of the necropolis of the Beja region, namely in Vinha das Caliças 4 , in which they unusually outnumber 'black' eye beads, with 84 examples $-c .10 .6 \%$ of the total glass assemblage (Gomes, 2015: 86; cf. also Arruda et al., 2017) (Fig. 5, n. 6)-, but also in Tomb 38 of the Quinta do Castelo necropolis, where four more examples were documented (Calvo and Simão, 2017: 404 and fig. 5).

A second formal group of 'black' glass beads, less common but still well represented in Southern Portuguese sites, includes cylindrical beads decorated with spiral threads of white glass. These threads were in some cases left more or less unaltered, generating a striped appearance, while in other cases they were combed or raked to generate waved or feathered patterns.

Examples of this type of bead have been documented in the necropolis of Fonte Velha de Bensafrim -one example, $0.3 \%$ of the total glass assemblage (Gomes, 2020: 103-104) (Fig. 5, n. 7)-, in the Algarve region, as well is in those of Herdade do Gaio -three examples, c. $0.9 \%$ (Costa, 1967; 1972)-, Corte Margarida -one example (Deus and Correia, 2005: fig. 3)-, Herdade do Pêgo -two examples, 20 \% (Dias et al., 1971: 219)-, Cerro do Ouro -one example (Beirão and Gomes, 1984: 442)-, Quinta do Estácio 6 -one example (Pereiro et al., 2017: fig. 11) - and Quinta do Castelo -one example (Calvo and Simão, 2017: fig. 5)- all in the Lower Alentejo region.

Ediciones Universidad de Salamanca / 묘요
The only possible instance of one such bead in a non-funerary context was retrieved in Faro by $\mathrm{S}$. Estácio da Veiga (2005 [1891]: est. XxviII, n. 9), although the chronology of this piece is unclear, and it could conceivably be much later in date.

Closely related to these cylindrical examples, some fusiform beads with similar chromatic and decorative patterns have also been documented, namely in the necropolis of Ameixial (vv. AA., 2017: 252) (Fig. 5, n. 8), Almograve (Veiga, 2005 [1891]: est. Xxxi; Vilhena 2014: fig. 5), Corte Margarida (Deus and Correia, 2005: fig. 3) and Herdade do Pêgo (Dias et al., 1971: 219), which have yielded one example each.

An example from the funerary assemblage of Favela Nova could be added to this list, although the small fusiform 'black' bead retrieved in this site (Dias and Coelho, 1983: 201-202) does not show any decoration, which makes it the only undecorated example in the currently known Southern Portuguese corpus. It is therefore one of only two such examples thus far documented in southwestern Iberia, together with a single spherical bead from the necropolis of Medellín, Badajoz (Almagro-Gorbea, 2008: 397), not considered in this work.

Finally, closing this typological survey of Pre-Roman 'black' glass beads, a mention must be made to a single biconical example with a feathered white decoration retrieved in the necropolis of Fonte Velha de Bensafrim $-0.3 \%$ of the total assemblage (Gomes, 2020: 105) (Fig. 5, n. 9). The unique nature of this bead, and the somewhat peculiar nature of the glass used in its production, which is dull, porous, but also compact and heavy, set it somewhat apart from the remainder of the pieces considered here, and it would merit further study in the future.

\subsection{Observations on the corpus: distribution, chronology and use of Pre-Roman 'black' glass beads in Southern Portugal}

Apart from establishing a first overall assessment of the typology of 'black' glass beads, the survey presented in the previous pages shows some particular 
and potentially relevant trends with regard to this specific group of Pre-Roman glass objects, including their geographical concentration in a relatively well-defined area, the comparatively short time span in which they circulated, and their clear association with funerary contexts.

Regarding the first of these aspects, it will by now be clear that 'black' glass beads are clearly concentrated in Southern Portugal, while being noticeably absent or at least very rare in neighboring regions. Furthermore, their distribution seems to define a well delimited area comprising the sub-coastal and inner areas of the Algarve region and most of the Lower Alentejo (Fig. 2), which during the Early Iron Age were eminently rural areas.

The presence of 'black' glass beads in other areas can be said to be residual, with only a minor number of examples being documented in the Lower Estremadura $^{6}$, in Central/ Northern Alentejo (Fabião, 2001: 204), and, further inland, in the Spanish Extremadura (Jiménez Ávila, 2001: 116).

While suggestive in itself, this pattern becomes particularly striking when compared to the much wider distribution of other types of glass beads, namely the ubiquitous monochrome dark blue spherical to annular beads and the equally widespread turquoise eye beads -for recent syntheses, see Arruda et al., 2016 and Gomes, 2020: 94-95; 96-99-, the distribution of which is much wider, and which have also been found in a more diversified range of functional contexts.

The rather limited distribution of 'black' glass beads, on the other hand, seems to correlate closely to that of other unusual bead types, such as colorless, greenish, and yellowish tubular beads (Gomes, 2020: 102-103), among others, which would deserve a dedicated study in their own right. This apparent correlation could therefore suggest the existence of different supply chains, but also of different communities of taste among the Early Iron Age communities of Southern Portugal.

With regard to the second relevant aspect highlighted by the survey above, that of chronology, it

6 Filardi, op. cit. n. 2. should be noted that, as previously mentioned, the 'black' glass beads seem to have circulated in Southern Portugal during a specific and comparatively short period, especially when compared to the longlived blue beads. In fact, and while a full discussion of the chronology of each site and assemblage is beyond the scope of this contribution - $c f$. bibliography above-, it can be said that the overwhelming majority of the beads listed above could be securely or tentatively dated within the $6^{\text {th }}$ century вс.

This is certainly the case with the examples from the enclosure necropolis of the Beja region, the chronology of which seems to fall primarily within that period, and is in all likelihood also true for most of the assemblages from the cist necropolis of Algarve and Alentejo and the tumular necropolis of the Ourique region $-c f$. bibliography above-.

This being said, it should be conceded that some assemblages may indicate a somewhat longer lifespan for these 'black' glass beads. Such examples include those from Tomb 4 of the necropolis Pardieiro, one of the latest contexts within that funerary site (Beirão, 1990: 111), as well as those found with the urn burial of Cerro do Ouro, in which the cremated remains were contained in a vessel which cannot be dated before the $5^{\text {th }}$ century BC (Beirão and Gomes, 1984: 442). While their stratigraphic position is unknown, the examples from Vaiamonte could also be comparatively late, which would explain the small percentage of 'black' glass in such a large and representative assemblage (Fabião, 2001).

These examples could therefore suggest that, in some circumstances, 'black' glass beads may still have been in use and circulation during the $5^{\text {th }}$ century BC, a period which has otherwise been considered as the high point in the diffusion and consumption of Pre-Roman glass in Southwestern Iberia (Jiménez Ávila, 2002-2003: 92-93). This could however be the result of relatively long periods of use for these pieces, which would be understandable given their exotic and apparently socially valued nature, even without resorting to the pillage of valuable objects from older tombs as an explanation (as in Beirão and Gomes, 1984: 442). 
Finally, a brief note must be added here regarding the third aspect mentioned above, namely the clear association of these 'black' beads with funerary contexts. This is not necessarily a specific characteristic of these elements, since in this period and area glass beads in general -as well as those in other exotic materials- are overwhelmingly concentrated in tombs ( $c f$. Gomes, 2014). However, as was already mentioned, blue beads do appear in a somewhat more diversified array of functional contexts, so the link between 'black' glass and funerary dress and adornment still seems worth highlighting.

In light of these observations, which clearly show that 'black' glass adornments form a very particular and cohesive group within the overall Pre-Roman glass assemblages, it seems necessary to reflect on their global context and on the historical, technological and economic context in which they made their way to the Atlantic façade of the Iberian Peninsula.

\section{Contextualizing the Southern Portuguese Early Iron Age 'black' glass: data, problems, and perspectives}

To assess the specific position of the Southern Portuguese 'black' glass beads discussed above in the overall framework of Pre-Roman glass production and circulation in the Mediterranean and its peripheries is no easy task.

In fact, in-depth morphologic and decorative studies which could offer good comparanda remain rare, while archaeometric methods which have shed considerable light on other facets of glass history are only now beginning to make some headway on the study of Early Iron Age glass. This being said, some further considerations can be made on this subject based on the typological and compositional data available.

Regarding the first aspect, it should be said that the 'black' eye beads which form the largest part of the corpus discussed above have very few clear parallels beyond the area considered in this study. In fact, and while they can clearly be related to the broad family of the 'eye' beads, which was one of the more widespread features of Pre-Roman glass in the Mediterranean (Spaer, 1985; Ruano, 1995a) as well as in Europe (Venclová, 1983), examples which match the Portuguese material in color and scheme are hard to identify in the published literature.

Possible parallels could however be found in Carthage's tophet, in which $6^{\text {th }}-5^{\text {th }}$ century BC 'black' eye beads have been reported (Eremin et al., 2012), but no clear-cut examples of the type in discussion have been found in other available repositories of Punic glass beads (Uberti, 1993; Giammelaro, 2008; Arveiller-Dulong and Nenna, 2011: 99140). M. Spaer, on the other hand, indicates that this type of bead is rare in the Eastern Mediterranean (Spaer, 2001: 82).

Rarer still are the 'black' eye beads with applied yellow granules, although the latter decorative solution is routinely found in other eye beads, namely blue and white ones (Gomes, 2020: 102). The examples from Fonte Velha de Bensafrim with compound eye motifs ( $c f$. Haevernick 1981), in particular, follow a very uncommon scheme, although they may have a very close parallel in a bead from Ibiza (Ruano, 1996: fig. 8, n. 3).

The spherical to sub-spherical beads with waved line decorations, on the other hand, pose a host of problems of their own. This very particular decorative motive is not reported in other Early Iron Age assemblages in the rest of the Iberian Peninsula (Ruano, 2000), with the exception of one example from Ampurias, to which a few more from Ibiza can be added (Matthäus, 1983: 60). The chromatic scheme of these examples -blue with white decorations- does not match that of the Portuguese material.

On the other hand, however, this type of bead is a very common feature of Pre-Roman glass bead repertoires in Central Europe. The so-called Perlen mit Zickzackzier, especially characteristic of the $6^{\text {th }}$ and early $5^{\text {th }}$ centuries BC, are in fact abundant, although no 'black' and white examples have been reported (Matthäus, 1983). This decorative group seems to also have spread further North, to 
the British Isles, where beads with waved line decorations, while not abundant, are well documented (Guido, 1978: 62-65; Foulds, 2017: 260).

Beads with waved line decorations are, on the other hand, rare in the Mediterranean. 'Black' and yellow examples from the Lydian capital of Sardis (Turkey) have recently been reported (Van HamMeert et al., 2019), which can now be added to a few blue and white examples previously known from other coastal Turkish sites (Matthäus, 1983: 64), as well as to the residual brown and white examples known from Cyprus (idem: 86). Still, the type remains rare in the Eastern Mediterranean as a whole.

Further West, the picture is somewhat more complex, as beads with waved lines are virtually unknown in the repertoires of the Punic Mediterranean (Uberti, 1993; Giammelaro, 2008; Arveiller-Dulong and Nenna, 2011: 99-140), but are relatively well represented in the Italian Peninsula, particularly in Central Italy (Matthäus, 1983: Karte 1; Koch, 2011: 65-66), although again with very different color schemes to the Portuguese material.

The relation between the Portuguese material and the wider group of beads with waved line remains unclear, but it can be suggested that Italy may have played a role in the introduction of some beads of the type in question -or at least of the idea of beads with waved line decorations- in the Mediterranean trade and craft circuits. This hypothesis is particularly interesting in this context since the consumption of 'black' glass is also well attested in Italian contexts (Conte et al., 2018).

Unlike the spherical beads discussed so far, cylindrical 'black' beads seem to have been a somewhat more common occurrence beyond the Portuguese territory. In the Iberian Peninsula, for instance, examples are reported from Castillo de Dońa Blanca, Cádiz (Ruano, 2001: 58), and from the Iberian necropolis of La Albufereta, Alicante (Ruano, 1995b: 194). Other parallels can be found in several Punic sites of the Western and Central Mediterranean, including Ibiza (Ruano, 1996: fig. 12; mapa n. ${ }^{\circ}$. 5; 2000: 75), Mozia, Sicily (Giammelaro, 2008: Tav. XIx), and possibly Tharros, Sardinia (Uberti,
1993: tav. XvI), while many more similar examples with a reportedly very dark blue matrix are also to be found in other Punic sites (Arveiller-Dulong and Nenna, 2011: 99-140). Ultimately, the origin of these beads could be traced back to the Eastern Mediterranean, where some examples are also documented (Spaer 2001: 100).

Beyond the specifically 'black' examples, it must be said that cylindrical beads with threaded decorations are fairly common in other areas and cultural environments too, including Italy (Koch, 2011: 7-72). They also seem to have enjoyed a very prolonged popularity, remaining in production during Roman times, namely once again in 'black' glass (Cosyns, 2011: 110).

One final note on the subject of typological comparanda should be made with regard to the uncommon biconical bead from Fonte Velha de Bensafrim discussed above. While this piece has no close parallels in any reported material from the Iberian Peninsula and the Western Mediterranean, an almost similar bead has been retrieved in an unspecified context of the Phoenician-Punic site of Mozia (Giammelaro, 2008: tav. XIX, n. 125), once again suggesting a connection between the Portuguese material and the Punic world.

As can be gauged by this short discussion, comparative typological analyses, while suggestive, do not in this case shed much light on the issue of the origin and possible distribution routes of the 'black' glass beads considered here. It would therefore be useful to count with other strands of evidence to advance in this discussion, in particular analytical data obtained through archaeometric analyses.

Unfortunately, as mentioned above, archaeometric research on Pre-Roman glass in Southern Portugal remains residual, and very little analytical data is available for any type of comparative study. With regard to black glass, in particular, the only useful results so far reported in literature regard two 'black' beads which formed part of the large assemblage from the necropolis of Vinha das Caliças 4 (Costa et al., 2019: nn. 1 and 10).

While the number of analyzed samples is very reduced and, therefore, of very limited statistical 
value, a comparison between the compositional results reported by M. Costa and colleagues (2018) with those from other Early Iron Age 'black' glass assemblages in the Near East, the Mediterranean and Europe (Reade et al., 2009; Purowski et al., 2012, 2020; Conte et al., 2016; 2018; Agua et al., 2017; Van HamMeert et al., 2019) still yields some suggestive results.

First of all, a comparison of the content in magnesia and potash (Fig. 6a), two oxides usually introduced in the glass mix mostly with the flux (Degryse and Shortland, 2020: 10-11), not only shows that these samples fall well within the LMG -or natron glass- category, as was to be expected given their chronological and geographical setting, but also that they are placed towards the lower magnesia/potash end of the spectrum within that category, suggesting the raw materials used for the production of these glasses were quite pure. In this regard, these Portuguese samples plot very close to the roughly contemporary Carthaginian glasses studied by K. Eremin and colleagues (2012), as well as, to a lesser extent, to some of the Polish samples studied by T. Purowski and colleagues $(2012,2020)$.

The same could be said about the lime contents of the Portuguese samples (Fig. 6b), which once again plot very closely with the Carthaginian (Eremin et al., 2012), and, to a less extent, with the Polish examples (Purowski, 2012, 2020). On the other hand, the soda content of the western beads (Fig. 6c), which is also very low, falls below the levels of the other assemblages considered, although
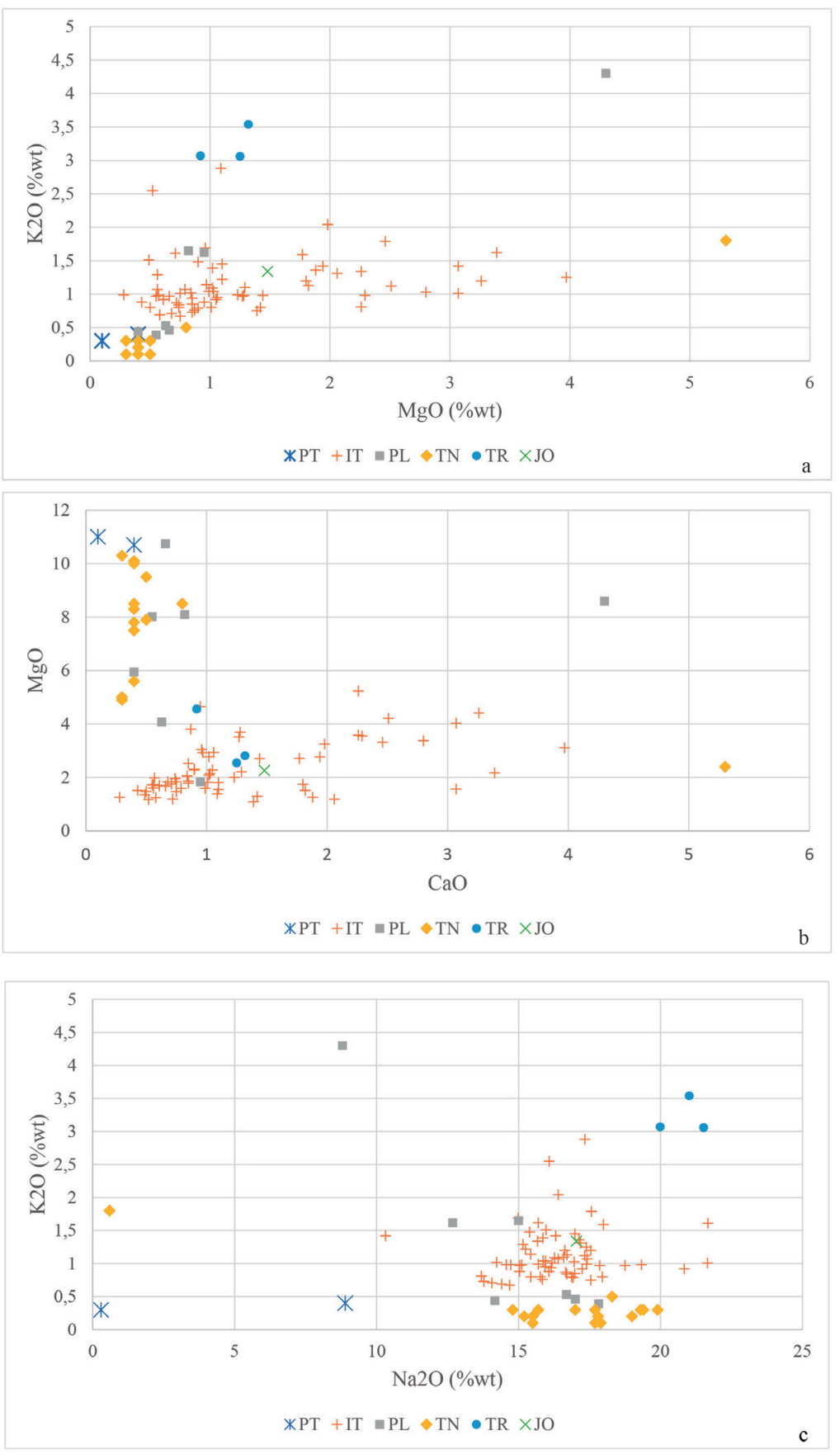

FIG. 6. Scatter plots of a) magnesia versus potash (\%wt), b) magnesia versus lime (\%wt) and c) potash versus soda (\%wt) for the Vinha das Caliças 4 samples (Costa et al., 2019) compared to Early Iron Age 'black' glass from Italy (Conte et al., 2018), Poland (Purowski et al., 2012, 2020; Agua et al., 2017), Tunisia - Carthage (Eremin et al., 2012), Turkey - Sardis (Van Ham-Meert et al., 2019) and Jordania - Pella (Reade et al., 2009 - only the average of the obtained results is given). 

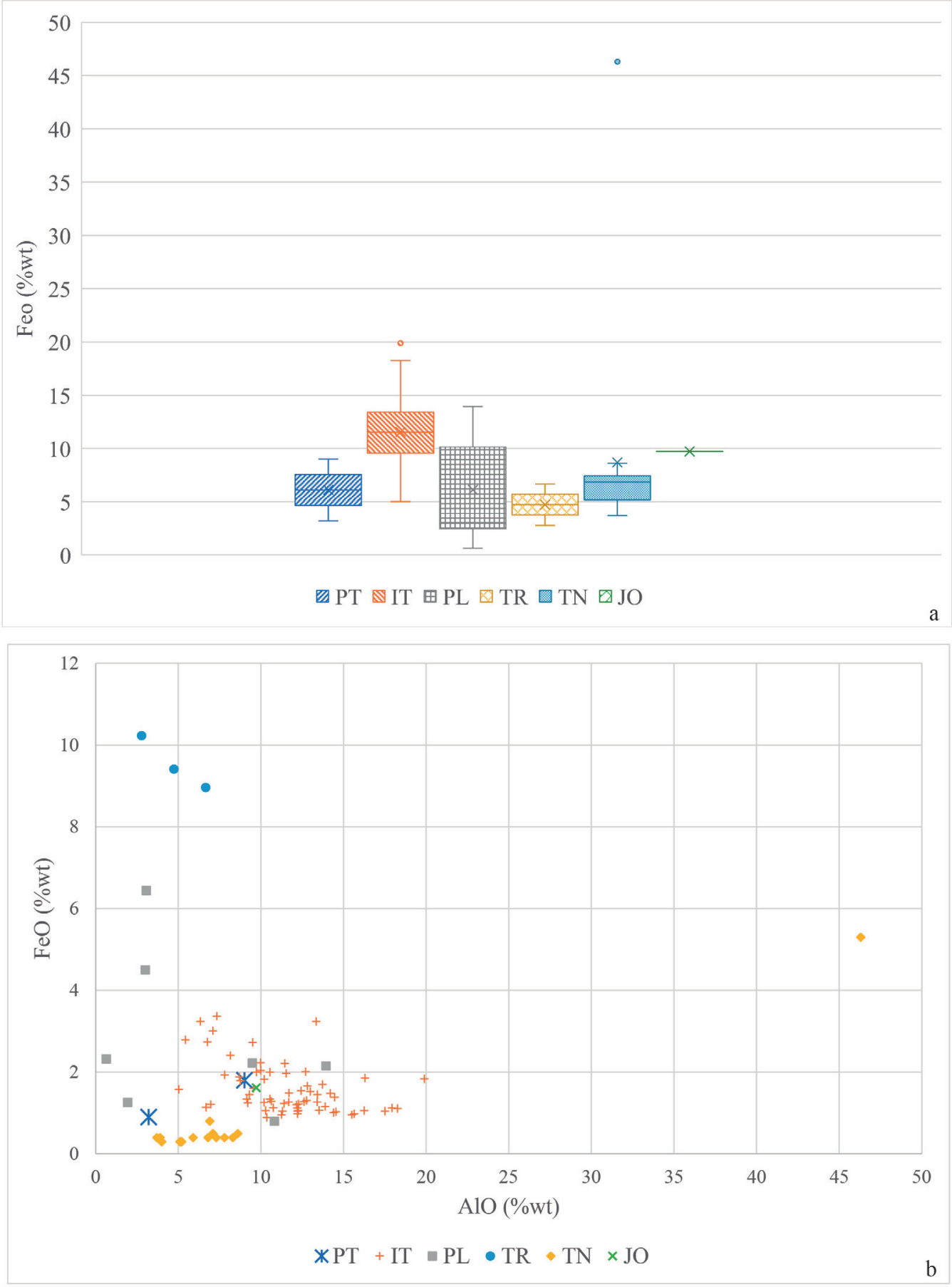

FIG. 7. a) Box plot showing the range of iron oxide (\%wt) in the composition of 'black' glass from Vinha das Caliças 4 (Costa et al., 2019) in comparison with that from other areas: Italy (Conte et al., 2018), Poland (Purowski et al., 2012, 2020; Agua et al., 2017), Tunisia - Carthage (Eremin et al., 2012), Turkey - Sardis (Van Ham-Meert et al., 2019) and Jordania - Pella (Reade et al., 2009 - only the average of the obtained results is given); b) scatter plot of potash versus alumina (\%wt) for the same dataset. 
again comparatively close to one piece from Carthage (Eremin et al., 2012: sample 6393A).

Another important characteristic of Pre-Roman 'black' glass is its elevated iron content, which is responsible for its characteristic coloration. Since this is a technological feature of all the Pre-Roman 'black' glass groups so far documented, it is not surprising that there is a considerable overlap between different assemblages as far as iron content is concerned (Fig. 7a). This being said, the value bracket for the percentage of iron oxide per total weight in Portuguese samples once again is closer to that documented in the material from Carthage (Eremin et al., 2012) and Sardis (Van Ham-Meert et al., 2019) than to any of the other available data sets.

However, the similarities between the Portuguese and the Turkish samples are, in this case, more apparent than real, as the material from Sardis belongs to a very particular technological tradition of high-alumina glasses which is scarcely represented in other $1^{\text {st }}$ millennium BC assemblages (idem). In fact, when comparing iron and alumina contents (Fig. 7b) the Turkish samples are clearly shown to form a group of their own, while the material from Vinha das Caliças plots once again, at least in one case, very close to that from Carthage.

This proximity in iron content between both groups of samples is particularly significant since it has been hypothesized that the 'black' glass used for the Carthaginian samples was the result of the local addition of iron, possibly in the form of metallurgical slag, to raw glass imported from elsewhere, thus obtaining this particular type of deeply colored glass (Eremin et al., 2012). If this was indeed the case, then the similarities between both sets of samples would no longer be just an indication of the existence of a third common raw glass supply area, but an actual evidence that the Portuguese material was the product of secondary glass working taking place in Carthage.

As can clearly be observed, the available evidence remains somewhat anecdotal, and the comparative results presented above could easily be changed with the addition of new data. However, the typological resemblance between at least some

Ediciones Universidad de Salamanca / ๑®@ of the Portuguese beads and similar material found in Punic contexts of the Central and Western Mediterranean paired with the compositional closeness between the Portuguese samples and those from the North African Punic metropolis of Carthage seem very suggestive, especially since they fit well with the chronology of the Portuguese 'black' glass assemblages and the historical framework of the period in question.

It is in fact well known that Carthage assumed a renewed importance in the framework of the Phoenician diasporic network after the fall of Tyre in 572 вс (González Wagner, 1994), and it is commonly assumed that the Punic metropolis played a key role in the direct or indirect distribution to the West of a vast array of exotic and prestigious materials, including amulets (Feghali-Gorton, 1996: 148; López Grande et al., 2014: 83-85), ostrich eggshells (Savio, 2004), but also very likely glass objects.

Although the possible circumstances surrounding the break in the supply of 'black' glass to the area under study are less clear cut, in the light of the evidence it is also tempting to see it as a reflection of the consolidation of an autonomous Western Punic block, spearheaded by Gadir (Niveau de Villedary, 2001; see also Arteaga, 1994), which, combined with the overall transformation of the social, political and trade networks of southwestern Iberia in the wake of the so-called ' 6 'th century crisis', may well have dictated a shift in the provision routes of exotic and prestige goods to the area under study during the $5^{\text {th }}$ century BCE.

Therefore, and until new data comes to the fore which changes the current panorama, it seems at least plausible that the 'black' glass objects discussed here were introduced in Southern Portugal, either directly or indirectly, through Punic and specifically Carthaginian trade. This being said, the reason why beads with this particular chromatic scheme are apparently concentrated in Southern Portugal remains unclear. Perhaps an issue of taste was at work, with 'black' adornments incurring particular favor with the communities of this region, as suggested above. The existence of other, as yet unrecognized social, 
economic or trade factors underlying this particular distribution pattern should not however be excluded.

The discussion of the Pre-Roman 'black' glass beads of Southern Portugal is therefore far from closed, and this material should be revisited in the future through new studies of hitherto unpublished or only summarily published glass assemblages and especially of new archaeometric analyses. Only then will we be able to fully frame the material discussed here in a more structured reconstruction of the regional Iron Age networks of trade and consumption. Hopefully, this contribution will promote and foster new work which will produce these much-needed data and be useful for future discussions of this so far overlooked aspect of Early Iron Age material culture.

\section{Bibliography}

Agua, F.; Conde, J. F.; Kobylińska, U.; KobylińsKI, Z.; García-Heras, M. and Villeggas, M. Á. (2017): "Chemical-physical characterisation of Early Iron Age glass beads from Central Europe", Boletín de la Sociedad Española de Cerámica y Vidrio, 56 (3), pp. 119-130. Dor: https://doi.org/10.1016/j. bsecv.2017.03.001

Almagro Gorbea, M. (2008): "Cuentas de collar y botones”. In Almagro Gorbea, M. (dir.): La necrópolis de Medellín. II. Estudio de los Hallazgos. Madrid: RAH, pp. 395-399.

Arruda, A. M.; Barbosa, R.; Gomes, F. B. and Sousa, E. DE (2017): "A necrópole da Vinha das Caliças 4 (Beja)”. In JimÉnez Ávila, J. (ed.): Sidereum Ana III. El Río Guadiana y Tartessos. Mérida: Consorcio Ciudad de Mérida, pp. 187-225.

Arruda, A. M.; Pereira, C.; Pimenta, J.; Sousa, E. de; Mendes, H. and Soares, R. (2016): "As contas de vidro do Porto do Sabugueiro (Muge, Salvaterra de Magos, Portugal)", Cuadernos de Prehistoria y Arqueología de la Univ. Autónoma de Madrid, 42, pp. 79-101. DOI: https://doi.org/10.15366/cupauam2016.42.002

Arteaga, O. (1994): "La liga púnica gaditana: aproximación a una visión histórica occidental, para su contrastación con el desarrollo de la hegemonía cartaginesa, en el mundo mediterráneo". In Cartago, Gadir, Ebusus y la influencia púnica en los territorios hispanos. Ibiza: Museo Arqueológico de Ibiza, pp. 23-58.

Arveiller-Dulong, V. and Nenna, D. (2011): Les verres antiques du Musée du Louvre. 3, Parures, instruments et éléments d'incrustation. Paris: Musée du Louvre.

Barros, P.; Branco, G.; Duarte, C. and Correia, J. (2005): "A Cista dos Gregórios (Silves)", Xelb, 5, pp. 41-52.

Beirấ, C. De M. (1972): “Cinco aspectos da Idade do Bronze e da sua transição para a Idade do Ferro no Sul do País". In Actas II Jornadas da Associação dos Arqueólogos Portugueses. Lisboa: Associação dos Arqueólogos Portugueses, pp. 193-222.

Beirấ, C. DE M. (1986): Une Civilisation Protohistorique du Sud du Portugal (Ier Âge du Fer). Paris: Éditions du Boccard.

Beirấ, C. de M. (1990): "Epigrafia da Idade do Ferro do Sudoeste da Península Ibérica. Novos dados arqueológicos", Estudos Orientais, I, pp. 107-118.

Beirão, C. de M. and Gomes, M. V. (1984): "Coroplastia da I Idade do Ferro do Sul de Portugal”. In Volume d'Hommage au Géologue Georges Zbyszewsky. Paris: Éditions Recherches sur les Civilisations, pp. 450-482.

Bотто, J. (1899): Glossario critico dos principaes monumentos do Museu Archeologico Infante D. Henrique. Faro: Tipographia E. Seraphim.

Cagno, S.; Cosyns, P.; Izmer, A.; Vanhaecke, F.; Nys, C. and Janssens, K. (2014): "Deeply colored and black-appearing Roman glass: a continued research", Journal of Archaeological Science, 42, pp. 128-139. DoI: https://doi.org/10.1016/j.jas.2013.11.003

Calvo, E. and Simâo, P. (2017): "La sepultura 38 de Quinta do Castelo 5 (Salvada, Beja)". In Jiménez Ávila, J. (ed.): Sidereum Ana III. El Río Guadiana y Tartessos. Mérida: Consorcio Ciudad de Mérida, pp. 399-405.

Conde, J. F.; Agua, F.; Maldonado, S.; De Torres, J.: Pereira, J.; Villegas, M. A. and García-Heras, M. (2016): "Caracterización y estudio arqueométrico de un conjunto de vidrios de la Edad del Hierro de la necrópolis de Palomar de Pintado (Toledo, España)", digitAR, 3, pp. 83-92. DoI: https://doi. org/10.14195/2182-844X_3_10

Conte, S.; Arletti, R.; Henderson, J.; Degryse, P. and Blomme, A. (2018): "Different glassmaking technologies in the production of Iron Age black glass from Italy and Slovakia”, Archaeological and

Zephyrus, LXXXVII, enero-junio 2021, 125-144 
Anthropological Sciences, 10, pp. 503-521. DOI: https://doi.org/10.1007/s12520-016-0366-4

Conte, S.; Arletti, R.; Mermati, F. and Gratuze, B. (2016): "Unravelling the Iron Age glass trade in Southern Italy: the first trace-element analyses", European Journal of Mineralogy, 28, pp. 409-433. DOI: https://doi.org/10.1127/ejm/2016/0028-2516

Costa, J. M. dA (1967): "O tesouro Fenício ou Cartaginês do Gaio (Sines)”, Ethnos, 5, 529-537.

Costa, J. M. DA (1972): “O tesouro púnico-tartéssico do Gaio”. In Actas II Jornadas da Associação dos Arqueólogos Portugueses. Lisboa: Associação dos Arqueólogos Portugueses, pp. 97-120.

Costa, M.; Arruda, A. M.; Dias, L.; Barbosa, R.; Mirão, J. and Vandenabeele, P. (2019): "The combined use of Raman and micro-X-ray diffraction analysis in the study of archaeological glass beads", Journal of Raman Spectroscopy, 50 (2), pp. 137-142. DOI: https://doi.org/10.1002/jrs.5446

Cosyns, P. (2011): The production, distribution and consumption of black glass in the Roman Empire during the $1^{\text {st }}-5^{\text {th }}$ century $A D$. An archaeological, archaeometric and historical approach. Brussels: Vrije Univ. Brussel.

Degryse, P. and Shortland, A. (2020): "Interpreting elements and isotopes in glass: a review", $A r-$ chaeometry, 62 (s1), pp. 117-133. Dor: https://doi. org/10.1111/arcm.12531

Deus, M. De and Correia, J. (2005): "Corte Margarida. Mais uma necrópole orientalizante no Baixo Alentejo". In Celestino Pérez and S. and Jiménez Ávila, J. (eds.): El Periodo Orientalizante. Madrid: csic, pp. 615-618.

Dias, M. ${ }^{a}$ M. A.; Beirấo, C. De M. and Coelho, L. (1971): "Duas necrópoles da Idade do Ferro no Baixo-Alentejo: Ourique. (Notícia preliminar)”, $O$ Arqueólogo Português, 3 (4), pp. 175-219.

Dias, M. ${ }^{a}$ M. A. and Coelho, L. (1983): "Objectos arqueológicos dum túmulo de incineração da necrópole proto-histórica da Herdade da Favela Nova (Ourique)", O Arqueólogo Português, 4 (1), pp. 197-206.

Eisen, G. (1916): “The Characteristics of Eye Beads from the Earliest Times to the Present", American Journal of Archaeology, 20 (1), pp. 1-27.

Eremin, K.; Degryse, P.; Erb-Satullo, N.; Ganio, M.; Greene, J.; Shortland, A.; Walton, M. and Stager, L. (2012): "Iron Age glass beads from Carthage". In Meers, N.; Cartwright, C.; Meek, A. and Mongiatti, A. (eds.): Historical Technology,
Materials and Conservation. SEM and Microanalysis. London: Archetype, pp. 30-35.

Fabiấ, C. (2001): "Importações de origem mediterrânea no interior do sudoeste peninsular na segunda metade do I milénio a. C.: materiais da Cabeça de Vaiamonte, Monforte". In Os Púnicos no Extremo Ocidente. Lisboa: Univ. Aberta, pp. 197-228.

Feghali-Gorton, A. (1996): Egyptian and Egyptianizing Scarabs. A typology of steatite, faience and paste scarabs from Punic and other Mediterranean sites. Oxford: Oxford University Committee for Archaeology.

Figueiredo, M. and Mataloto, R. (2017): "Necrópoles rurais sidéricas do Baixo Alentejo setentrional: sociedade e mundo funerário nos Barros de Beja”. In Jiménez Ávila, J. (ed.): Sidereum Ana III. El Río Guadiana y Tartessos. Mérida: Consorcio Ciudad de Mérida, pp. 353-398.

Foulds, E. M. (2017): Dress and Identity in Iron Age Britain. A study of glass beads and other objects of personal adornment. Oxford: Archaeopress.

García-Heras, M.; Rincón, J. M.; Jimeno, A. and Villegas, M. A. (2005): "Pre-Roman coloured glass beads from the Iberian Peninsula: a chemico-physical characterisation study", Journal of Archaeological Science, 32, pp. 727-738. Dor: https://doi. org/10.1016/j.jas.2004.12.007

Giammelaro, A. S. (2008): I Vetri della Sicilia Punica. Rome: Bonsignori.

Gomes, F. B. (2014): "Importaçốes mediterrâneas em contextos 'Pós-Orientalizantes' do Sul de Portugal (séculos VI-IV a.n.e.)", Onoba, 2, pp. 27-44.

Gomes, F. B. (2015): "Mediterranean goods in 'Post -Orientalizing' funerary contexts of Southern Portugal: some remarks on consumption, peripherality and cultural identity". In Álvarez Martínez, J. M. ${ }^{a}$; Nogales, T. and RodÀ, I. (eds.): Centro y Periferia en el Mundo Clásico. Actas XVIII Congreso Internacional de Arqueología Clásica. Mérida; MNAR, vol. I, pp. 435-438.

Gomes, F. B. (2020): “O conjunto vítreo da necrópole da I Idade do Ferro da Fonte Velha de Bensafrim (Lagos)", Ophiussa, 4, pp. 71-116.

González Wagner, C. (1994): "El auge de Cartago (ss. VI-IV) y su manifestación en la Península Ibérica". In Cartago, Gadir, Ebusus y la influencia púnica en los territorios hispanos. Ibiza: Museo Arqueológico de Ibiza, pp. 7-22.

Gratuze, B. (2009): "Les premiers verres au natron retrouvées en Europe Occidentale: composition chimique et chrono-typologie". In Janssens, K.; 
Degryse, P.; Cosyns, P.; Caen, J. and Van't Dack, L. (eds.): Annales du $17^{e}$ Congrès de l'Association Internationale pour l'Histoire du Verre. Antwerpen: Association International pour l'Histoire du Verre, pp. 8-14.

Guido, M. (1978): The Glass Beads of the Prehistoric and Roman Periods in Britain and Ireland. London: Society of Antiquaries.

HaEvernick, T. (2013): "Perlen mit zusammengesetzen Augen ('compound-eye-beads')". In Haevernick, T.: Beiträge zur Glasforschung: Die wichtigsten Aufä̈tze von 1938 bis 1981. Mainz: Verlag Philipp von Zabern, pp. 233-244.

Henderson, J. (2013): Ancient Glass. An Interdisciplinary Exploration. Cambridge: cup.

Jiménez Ávila, J. (2001): "La necrópolis de 'El Jardal' (Herrera del Duque, Badajoz): elementos para el estudio del ritual funerario del suroeste de la $1 .^{a}$ Edad del Hierro", Complutum, 12, pp. 113-122.

JimÉNeZ ÁviLA, J. (2002-2003): "Estructuras tumulares en el Suroeste Ibérico. En torno al fenómeno tumular en la Protohistoria peninsular", Boletín de la Asociación Española de Amigos de la Arqueologia, 42, pp. 81-120.

Косн, L. (2011): Früheisenzeitliches Glas und Glasfunde Mittelitaliens. Bochum: Verlag Marie Leidorf.

López-Grande, M. J.; Velázquez, F.; Fernández, J. H. and MezQuida, A. (2014): Amuletos de iconografía egipcia procedentes de Ibiza. Ibiza: Museo Arqueológico de Ibiza y Formentera.

Martínez Mira, I. and Vilaplana Ortego, E. (2014): "Cuentas de collar de La Fonteta (Guardamar, Alicante) y La Peña Negra (Crevillente, Alicante): descripción y análisis instrumental". In González Prats, A. (ed.): La Fonteta-2. Estudio de los materiales arqueológicos hallados en la colonia fenicia de la actual desembocadura del río Segura (Guardamar, Alicante). Alicante: Univ. de Alicante, pp. 848-931.

MatтhäUs, H. (1983): "Perlen mit Zickzackzier". In Glasperlen der vorrömischen Eisenzeit. Marburg: Univ. of Marburg, pp. 1-128.

Niveau-de-Villedary, A. M.a (2001): "El espacio geopolítico gaditano en época púnica. Revisión y puesta al día del concepto de "Círculo del Estrecho'", Gerión, 19, pp. 313-354.

Palomar, T.; Peña Poza, J. and Conde, J. F. (2009): "Cuentas de vidrio prerromanas y Arqueometría: Una valoración de los trabajos realizados en la Península Ibérica", Zephyrus, Lxiv, pp. 53-62.
Pereiro, T.; Mataloto, R. and Borges, N. (2017): "Alentejo, a Sul de Beja: a necrópole da Quinta do Estácio 6". In Jiménez Ávila, J. (ed.): Sidereum Ana III. El Río Guadiana y Tartessos. Mérida: Consorcio Ciudad de Mérida, pp. 303-331.

Purowski, T.; Dzierżanowski, P.; Bulska, E.; WaGNER, B. and NowaK, A. (2012): "A study of glass beads from the Hallstatt C-D from southwestern Poland: Implications for glass technology and provenance", Archaeometry, 54, pp. 144-166. Dor: https:// doi.org/10.1111/j.1475-4754.2011.00619.x

Purowksi, T.; Syta, O. and Wagner, P. (2020): "Between East and West: glass beads from the eighth to third centuries BCE from Poland", Archaeometry, 62 (4), 752-773. DoI: https://doi.org/10.1111/ $\operatorname{arcm} .12563$

Reade, W.; Freestone, I. and Bourke, S. (2009): "Innovation and continuity in Bronze and Iron Age glass from Pella in Jordan”. In Janssens, K.; Degryse, P.; Cosyns, P.; Caen, J. and Van't Dack, L. (eds.): Annales du $17^{\circ}$ Congrès de l'Association Internationale pour l'Histoire du Verre. Antwerpen: Association Internationale pour l'Histoire du Verre, pp. 47-54.

Ruano Ruiz, E. (1995a): "Cuentas polícromas prerromanas decoradas con 'ojos"', Espacio, Tiempo y Forma. Série II. Historia Antigua, 8, pp. 255-286.

Ruano Ruiz, E. (1995b): "El collar con cuentas y colgantes de vidrio de la tumba n. ${ }^{\circ} 33$ de La Albufereta (Alicante)", Boletín de la Sociedad de Amigos de la Arqueologia, 35, pp. 193-203.

Ruano Ruiz, E. (1996): Las cuentas de vidrio prerromanas del Museo Arqueológico de Ibiza y Formentera. Ibiza: Museo Arqueológico de Ibiza.

Ruano Ruiz, E. (2000): Las cuentas de vidrio halladas en España desde la Edad del Bronce hasta el Mundo Romano. Madrid: Stock Cero.

Ruano Ruiz, E. (2001): "El vidrio antiguo (siglo viII al Iv a. C.). El Castillo de Doña Blanca (El Puerto de Santa María, Cádiz). I. Las cuentas de vidrio procedentes del poblado del Castillo de Dońa Blanca, El Puerto de Santa María, Cádiz", Boletín de la Sociedad de Amigos de la Arqueología, 41, pp. 57-63.

Sánchez, A.; Tuñón, J. A.; Parras, D. J.; Montejo, M.; Lechuga, M. A.; Ceprián, B.; Soto, M. and LuQUe, Á. (2019): "MRS, EDXRF and GC-MS analysis for research on the ritual and funerary areas of Cerro de los Vientos (Baeza, Jaén, Spain). Native and Eastern Mediterranean influences", Journal of Archaeological Science: Reports, 28, s/p. DOI: https://doi. org/10.1016/j.jasrep.2019.102026

Zephyrus, LXXXVII, enero-junio 2021, 125-144

Ediciones Universidad de Salamanca / @®@ఠ 
Santos, F. J. C.; Antunes, A. S.; Deus, M. De and Grilo, C. (2017): "A necrópole de Palhais (Beringel, Beja)”. In Jiménez Ávila, J. (ed.): Sidereum Ana III. El Río Guadiana y Tartessos. Mérida: Consorcio Ciudad de Mérida, pp. 227-261.

SAvio, G. (2004): Le uova di struzzo dipinte nella cultura punica. Madrid: Real Academia de la Historia.

Sayre, E. V. and Smith, R. W. (1961): "Compositional Categories of Ancient Glass”, Science, 133 (3467), pp. 1824-1826.

Schlick-Nolte, B. and Werthmann, R. (2003): "Glass vessels from the burial of Nesikhons", Journal of Glass Studies, 45, pp. 11-34.

Schlick-Nolte, B. and Werthmann, R. (2010): "More Glass Beakers for Nesikhons: A Preliminary Report”, Journal of Glass Studies, 52, pp. 235-240.

Sснмidt, K. (2019): Glass and glass production in the Near East during the Iron Age: evidence from objects, texts and chemical analysis. Oxford: Archaeopress.

Shortland, A. (2012): Lapis Lazuli from the Kiln. Glass and Glassmaking in the Late Bronze Age. Leuven: LuP.

Shortland, A.; Schachner, L.; Freestone, I. and Tite, M. (2006): "Natron as a flux in the early vitreous materials industry: sources, beginnings and reasons for decline", Journal of Archaeological Science, 33, pp. 521-530. DoI: https://doi.org/10.1016/j. jas.2005.09.011

Soares, R. M.; Baptista, L.; Pinheiro, R.; Oliveira, L.; Rodrigues, Z. and Vale, N. (2017): "A necrópole da I Idade do Ferro do Monte do Bolor 1-2 (São Brissos, Beja)". In Jiménez Ávila, J. (ed.): Sidereum Ana III. El Río Guadiana y Tartessos. Mérida: Consorcio Ciudad de Mérida, pp. 263-303.

Soares, R. M. and Martins, A. (2013): "A necrópole da Nora Velha 2 (Ourique). Novos dados e interpretaçôes 20 anos após a sua escavação". In Arnaud, J. M.; Martins, A. and Neves, C. (coords.): Arqueologia em Portugal. 150 Anos. Lisboa: Associação dos Arqueólogos Portugueses, pp. 661-669.
Spaer, M. (1985): "Some Observations on the Stratified Mediterranean Eye-Beads of the First Millennium BC". In Annales du $10^{\circ}$ Congrès de l'Association Internationale pour l'Histoire du Verre. Amsterdam: Association Internationale pour l'Histoire du Verre, pp. 1-12.

Spaer, M. (2001): Ancient Glass in the Israel Museum. Beads and Other Small Objects. Jerusalem: The Israel Museum.

Stapleton, C. P. (2015): "Glass and Glaze Analysis and Technology from Hasanlu, Period IVB". In De Schauensee, M. (ed.): Peoples and Crafts in Period IVB at Hasanlu, Iran. Philadelphia: Univ. of Pennsylvania, pp. 87-102. DOI: https://doi. org/10.9783/9781934536384.87

Uberti, M. L. (1993): I vetri preromani del Museo Archeologico Nazionale di Cagliari. Rome: Bonsignori.

Van Ham-Meert, A.; Dillis, S.; Blomme, A.; Cahill, N.; Clateys, P.; Elsen, J.; Eremin, K.; Gerdes, A.; Steuwe, C.; Roeffaers, M.; Shortland, A. and Degryse, P. (2019): "A unique recipe for glass beads at Iron Age Sardis", Journal of Archaeological Science, 108, pp. 1-9. Dor: https://doi.org/10.1016/j. jas.2019.104974

VAsconcelos, J. L. DE (1919-1920): "Estudos sobre a epoca do ferro em Portugal", O Archeólogo Português, 1 (xxiv), pp. 99-107.

Veiga, S. P. M. E. DA (2005 [1891]): Antiguidades Monumentaes do Algarve. Faro: Univ. of Algarve, vol. 4.

Venclovì, N. (1983): "Prehistoric eye beads in Central Europe”, Journal of Glass Studies, 25, pp. 11-17.

VilhenA, J. (2014): "Acupunctura em Odemira: dois séculos de Arqueologia”. In Prista, P. (coord.): Atas do Colóquio Ignorância \& Esquecimento. Odemira: Município de Odemira, pp. 53-124.

vv. AA. (2017): Loulé. Territórios, Identidades e Memórias. Lisboa: INCM. 